This Section of Epidemiology and Psychiatric Sciences appears in each issue of the Journal and is dedicated to all forms of creative production born of an intimate and individual urge, often secretive, unbound from the conventional art system rules. Through short descriptions of the Outsider art work of prominent artists and new protagonists often hosted in community mental health services, this Section intends to investigate the latest developments of the contemporary art scene, where the distances between the edge and the centre are becoming more and more vague.

Carole Tansella, Section Editor

\title{
Something they never got 'em in the world': the Life and Times of Sabato Rodia's Towers in Watts
}

\section{Del Giudice}

Fordham University Press, New York, USA

Received 5 March 2015; Accepted 11 March 2015

Key words: Art monument, common ground, Italian diaspora, Watts Towers.
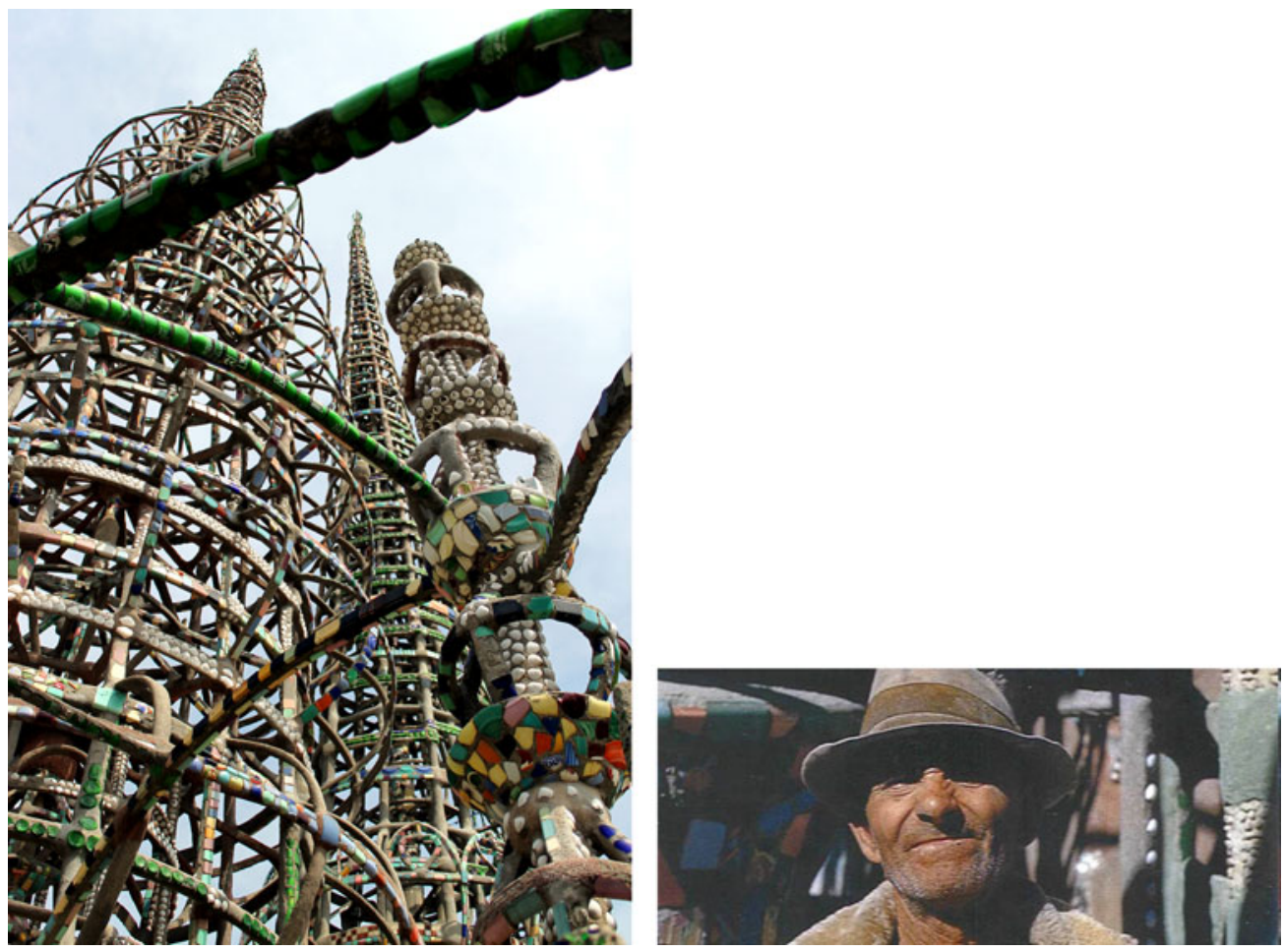

Left: Part of the Watts Towers complex. (Photograph by Luisa Del Giudice) Right: Photograph of S. Rodia by Jay Wayne.

Address for correspondence: L. Del Giudice, Fordham University Press, New York, USA.

(Email: luisadg@humnet.ucla.edu) 
The narrative of the 'Watts Towers' is as much a tale of the solitary, magnificent obsession of an unlettered Italian immigrant who was determined to build monumentally, as it is about extraordinary citizen action mobilised to save the monument from a city demolition order, as well as the inspiring site of community art in Los Angeles.

Sam, Simon - born Sabato - Rodia (1879-1965), an unlettered immigrant from Rivottoli di Serino (Avellino, Italy), was sent to the USA at the age of about 14 to live with an older brother in Pennsylvania, who dies shortly after in a mining accident. He goes West, marries, abandons wife and children, wanders (through the USA, Central and South America, Canada), and resurfaces in Long Beach, California in 1919, having given up drinking, with a new purpose in life. On a triangular plot of land in Watts he begins to build 'something big ... something they never got 'em in the world' (Landler \& Byer, 2006). From 1921 to 1954, alone, day after day, nights, weekends and holidays, he builds many towers (the tallest is $991 / 2 \mathrm{ft}$.), a ship, fountains, ovens, embedding the reinforced concrete with bits of tile, glass and seashells, picked up on the streets, beaches, railroad tracks (Dal Lago \& Giordano, 2008), signs it SR, and names the assemblage 'Nuestro Pueblo' (our town/our people). After suffering a stroke, he deeds the Towers to a neighbour, shuts the door, and walks away, never to return. He dies in Martinez (CA) in 1965, near family, because he did not want to die alone 'like a dog'. Years later, a group of aficionados finds the abandoned Towers, buys them, and creates a Committee to save them from a city demolition order, through a dramatic and successfully engineered 'stress test' in 1959, proving their stability. They then turn to preserving and promoting the Towers, and to offering free art classes to neighbourhood youth (the foundations of the still thriving community Watts Towers Arts Center). Only a month after Rodia's death, much of economically depressed and oppressed Watts is consumed in the Watts Riots/Rebellion, yet the Towers are left untouched, perceived to represent neutral ground or a common good.

By all accounts, the story of Rodia and the Watts Towers is extraordinary. But the questions around them endure: What do we call them? (Naif, outsider, avantgarde, visionary or folk art?). What are they? (A many-masted ship meant to take him on a long and impossible journey 'home'?). Why did he build them? (As an act of redemption for a misspent life? As a distant remembrance of lost landscapes?). And what are the cultural referents of artist, monument and arts campus over time?

Rodia lived on the periphery of many realities (e.g., family, culture, community), represents hybridity (linguistic, cultural) and contradiction (anticlerical and yet a preacher for a few years; intensely solitary artist and yet ever seeking to belong). He determined that by doing something 'good good good' rather than 'bad bad bad' (Landler \& Byer, 2006) he would be remembered by History, just like his heroes Italian explorers and builders. Rodia went to multiethnic Watts to build his magnum opus. He gave his monument a Spanish name. What was he trying to represent and embrace in the collective adjective? To whom does 'nuestro' refer? Elements of an Italian imaginary seem to be embedded in the work itself, e. g., towers, ships, treasure, as well as festive cultural practices (such as the dancing tower tradition of the 'Gigli of Nola'). The artist's Italian experience and his Italian diaspora experience are explored in Sabato Rodia's Towers in Watts: Art, Migrations, Development (Del Giudice, 2014), as well as the many contextualised meanings of the National Historic Landmark (e.g., in the Black Arts Movement, urban development, as World Heritage).

This living monument is situated in an ever evolving urban landscape and has many stakeholders - a chorus not always in harmony. But despite divergent trajectories there is also consensus and common ground: the Watts Towers remain a powerful symbol of spiritual resistance, vision and creativity. They offer hope for transcendence and tangible proof of what inspired creativity can unleash. Even a loner and drifter like Rodia, unable to properly fit in, could call upon inner resources, cultural memory and skills, to overcome suffering and defeat, to express the best of himself, and even to dazzle the world with his gifts. They show us how to make something beautiful from the broken and discarded stuff of life.

\section{References}

Dal Lago A, Giordano S (2008). Fuori Cornice: l'arte oltre l'arte. Einaudi: Torino.

Del Giudice L ed. (2014). Ed. Sabato Rodia's Towers in Watts: Art, Migrations, Development. Fordham University Press: New York.

Landler E, Byer B (2006). I Build the Tower. Bench Movies: Los Angeles.

\section{About the Author}

Luisa Del Giudice, Ph.D., is an independent scholar, former University Academic at the University of California, Los Angeles and at the Addis Ababa University and Founder and Director of the Italian Oral History Institute (Los Angeles, California). 
She has published and lectured widely on Italian and Italian American and Canadian folklife, ethnology, and oral history and has produced many innovative public programs on Italian, Mediterranean, regional, and folk culture and local history in Los Angeles.

In 2008 she was named an honorary fellow of the American Folklore Society and knighted by the Italian Republic.
She is the coordinator of the Watts Towers Common Ground Initiative and editor of Sabato Rodia's Towers in Watts: Art, Migrations, Development, New York: Fordham UP, 2014. In this book, Del Giudice's interdisciplinary approach provides a unique multifaceted and nuanced evaluation of Contemporary Outsider Art culture.

Carole Tansella, Section Editor 